\title{
STRUCTURAL EVALUATION OF THE CARTILAGE AND BONE TISSUE IN CATTLE FROM THE FUNCTIONAL AND MORPHOLOGICAL ASPECTS
}

\author{
H. CERNY \\ Department of Morphology, University of Veterinary Science, 61242 Brno
}

Received fune 27, 1979

\begin{abstract}
Cerny H.: Structural Evaluation of the Cartilage and Bone Tissue in Cattle from the Functional and Morphological Aspects. Acta vet. Brno, 49, 1980: 127-144.

The evaluation of morphological structures with regard to changes induced by disorders of mineral metabolism in 8 to 12-month old. bulls was performed in 82 cylinders of bone tissue obtained by osteobiopsy of the tuber coxae using a modified method according to Bartelheimer.

The bone cylindres were fixed immediately after sampling. Tissue sections were stained with hematoxylin and eosin, Azan and according to Goldner. Using various staining metods a number of correlates was obtained the evaluation of which gives a more objective view of the findings thus authorizing the wording of general conclusions.

The morphological examination of structures of bone bioptic samples shows that the disorders in mineral metabolism are induced by changes of the morphological structure which are, in young animals, manifested mainly on the apophyseal growth cartilage and in some cases on the trabeculae of the spongious bone.

Changes in the cartilage affect mainly its distal edge with a continuous enchondral ossification zone. The zone of the calcified hypertrophic cartilage is elongated and the individual hypertrophic chondrocytes are not arranged into columns but they form disarranged groups of cells. The ground substance of the cartilage is insufficiently mineralized, it is separated in fragments which shift into other ossification zones. In these they can be seen as atypical structures.

Demineralization affects also the trabeculae of the spongious bone; on their superficial, endostal regions and, in a smaller extent, around the lacunae and bone channels the formation of osteoid tissue was observed. In the histological preparations the osteoid tissue is very well differentiated in colour.

As the author's findings show, the methods of elaboration used enable - from the general point of view - to show the possibility of intravital diagnostics of structural changes occurring in cases of disorders of mineral metabolism.
\end{abstract}

Bone biopsy, apophyseal cartilage, spongious bone, mineral metabolism, demineralization, cattle.

The aim of the present paper is to give a survey of the possibilities of evaluating the morphological structure of the cartilage and bone tissue, the bone tissue obtained intravitally by biopsy from tuber coxae, in relation to metabolic disorders originating due to the lack of osteoplastic elements in feedlot bulls.

Another task to be solved is the identification of changes from the point of view of the evaluation of morphological structures of the bone tissue occurring in the individual structures and their comparison with normal conditions.

On the basis of knowledge obtained it is the aim to define the zonally occurring changes in the morphological structure which are of paramount importance with regard to further evaluation.

When evaluating literature data dealing with problems of the bone as an organ, or describing the individual constituents of bone tissue, it can be said that there are many papers dealing with this 
problem. The same as other tissues of the living organism, the bone tissue is also studied from various aspects using the most up-to-date means of contemporary techniques.

Even though the problem of mineralization of bone matrix has been known for many years, many authors devote adequate attention to this problem even now. Ascenzi (1964) studied the interrelationships between mineralization and the bone matrix. Bonnucci (1971) dealt with initial calcification of the cartilage and bone tissue. Alcock (1972), described the changes occurring in the course of mineralization of the cartilage; Dix on $(1970,1971)$ described the proliferation of cartilage cells and regional variation in the time cycle of cells in the epiphyseal cartilage. The hypertrophic chondrocyte (Holtrop 1972) and the ultrastructure of the epiphyseal plate was described by Scott, Pease (1956) and Holtrop (1972). In his paper Kember $(1960,1972)$ dealt with comparative patterns of cell division in epiphyseal cartilage. Mazhuga, Zhitnikov and Kharchuk (1970) proved that the cartilaginous part of the skeleton in the course of all the developmental periods of ontogenesis grew mainly from the middle part, represented by a differentiated structure formed into groups of flattened chondrocytes with a great proliferating ability. Wanken and Eyring - (1972) showed changes in the metabolic activity in various epiphyses with regard to age, W u thi er (1969) described the zonal analysis of organic and inorganic substances in epiphyseal cartilage during enchondral ossification. Another work dealing with cartilage metabolism is that of Campo, Bielen, Hetherington (1972) giving knowledge on protein-polysaccharides in cartilaginous tissue. Schenk, Spiro, Wiener (1976) dealt with cartilage resorption in the epiphyseal plate in connection with the growth activity of bones.

The bone tissue proper has been studied in literature from many morphological, functional and chemico-analytical aspects. From the point of view of studies of bone bioptic samples the works dealing with the structure of spongious bone tissue are of the greatest importance.

Dequeker et al. (1971) evaluated the ageing patterns of trabecular and cortical bone tissue and their relationship, Galante, Rostoker and Ray (1970) showed the physical properties of trabecular bone tissue and their importance when exposed to pressure. Merz and Schenk (1970) used quantitative structural analysis of the spongious structure of human bone tissue on the basis of measuring of superficial surfaces of the individual trabeculae. Using the same method Schenk, Merz, Müller (1969) evaluated quantitatively the resorption of trabeculae in spongiosa. Bonnucci et al. (1970) further evaluated the process of mineralization; on the basis of the density of osteoid bone tissue and osteons these authors show various degrees of mineralization of bone tissue.

More recent studies showed the dynamic mineralization system $\mathrm{CaO}-\mathrm{P}_{2} \mathrm{O}_{5}-\mathrm{H}_{2} \mathrm{O}$ operating under the co-action of the change of $\mathrm{pH}$ and pressure (Buggar 1966; Skinner 1974).

Along with the ground bone tissue proper attention in literature has been paid to cell elements of the bone tissue and cartilage. Knese and Knoop (1961) presented an extensive study on cells during chondrogenesis and osteogenesis using both light and electron microscope. In $1969 \mathrm{Knese}$ contributed to knowledge on the ultrastructure of skeleton cells; Walker (1972) showed the enzymatic activity of osteoclasts and Lucht (1973) described some of their organelles.

Another group of studies gives knowledge on the change of the structure of bone tissue in osteoporosis (Frost et al. 1966; Arnold 1960; Eger 1965). Renk (1961) presented the pathological changes of bone tissue in disorders of mineral metabolism in domestic animals, Theiler (1932) in cattle, Krupski et al. (1941) in cases of osteoporosis of animals.

Campo and Tourtellotte (1967) studied the chemical composition of bovine cartilage and bone, and Leach (1958) referred about the occurrence of lipids in compact cattle bone. Wuthier (1968) dealt with the problem of lipids in the course of mineralization of epiphyseal tissues in the bovine fetus. Field (1974) compared the different bone composition in cattle, pigs, sheep and poultry.

The most important for determining the generalized changes of the skeleton occurring with disorders of mineral metabolism are histological and histochemical examinations which together with chemical analysis of bone bioptic samples provide a real picture of the course and state of the changes. According to the biochemical finding in the blood serum the condition of osteopathy cannot be evaluated (Vokrouhlická, Horn, Erben 1975); only direct estimation of the bone structure can give satisfactory results. Intravital sampling - osteobiopsy - is being successfully used for obtaining bone tissue. The most convenient place for obtaining bone tissue seems to be tuber coxae; Graebner (1961) was the first to perform bone biopsy in cattle. Priborth (1966, 1967) performed biopsy for diagnostic purpose, for chemical analyses and for histological examinations of bioptic samples.

Also other authors, viz. Priboth, Sefner, Wujanz (1968) investigated the state of morpholological structure in bone bioptic samples with regard to mineral metabolism. The authors are of the opinion that demineralization of the bone tissue in the first stage does not occur on the surface of the individual trabeculae, as had been previously mentioned in literature, but that for the initial stage typical is the demineralization inside the trabeculae, i.e. in the surroundings of the 
lacunae and bone channels. At the same time the demineralization is accompanied by a change in the organic matter of the ground substance.

Histological and chemical examinations of bioptic samples of bone tissue were also successfully used for the estimation of the effect of industrial air pollution as a factor evoking skeleton changes (Sefner, Wujanz 1973).

\section{Materials and Methods}

Bone tissue together with apophyseal cartilage was obtained by osteobiopsy of tuber coxae using the method according to Bartelheimer from 82 Red Spotted bulls 8 to 12 months old.

Using a bone trocar of an inside diameter of $6 \mathrm{~mm}$ we obtained cylinders $30-40 \mathrm{~mm}$ long. Sampling of the material was performed in cooperation with workers from the Department of Diagnostics, Therapy and Prophylaxis of the University of Veterinary Science.

The material was fixed in $10 \%$ formol immediately after osteobiopsy.

Chelaton III produced by Lachema was used for decalcification of the bone tissue. After decalcification the material was embedded into paraffin or celoidin; part of the material was elaborated as not decalcified material. From the tissue blocks sections were prepared 4-7 $\mu \mathrm{m}$ thick and were stained with hematoxylin-eosin, Azan and according to Goldner.

Microphotographs were made using the automatic photographic equipment AFM 3 on black-and-white negative material ORWO NF 15 DIN.

\section{Results}

Microscopic conditions in a normal bone structure

The longitudinal section of the bone cylinder reveals several different structures. The superficial collagen or muscle fibres of the skeletal musculature are of no diagnostic importance, therefore, they will not be described in detail.

On the surface of the bone bioptic sample is the cartilage the ground substance of which has a decreased affinity to basophilic stains. Only the superficial layers of the cartilage stain blue, the other tissue, such as the hypertrophic cartilage calcified in the ossification centres shows enchondral mineralization and is, therefore, eosinophilic. Basic-staining are only the loci of chondrocytes arranged into isogenetic groups. Chondrocytes situated under the perichondrium are flattened, spindle-like, in the ossification centres they become globular. Characteristic for the middle layer is the growth of cartilage by intussusception appearing as mitotic activity of the chondrocytes. Apart from this the cartilage grows also by apposition through the differentiation of fibroblasts of the perichondrium in chondrocytes.

\section{Apophyseal growth cartilage}

A very important structure from the viewpoint of diagnostics of structural changes in bone bioptic samples occurring with disorders of mineral metabolism in young animals is the growth cartilage situated as apophyseal cartilage. As mentioned before, the thickness of the growth cartilage changes and this quantitative change is determined by the age of the animal.

Cartilage growth is influenced by the age; the growth potential is higher in younger animals than in the older ones. Cartilage growth occurs through intussusception in the middle layer. Characteristic for this layer is the fact that it consists of flattened chondrocytes with a great proliferation ability. The new chondrocytes shift towards the periphery of the cartilage becoming rounded in the process. Over the whole distal end of the growth cartilage a continuous ossification zone is formed. From the proximally situated enchondral ossification centres the primary 


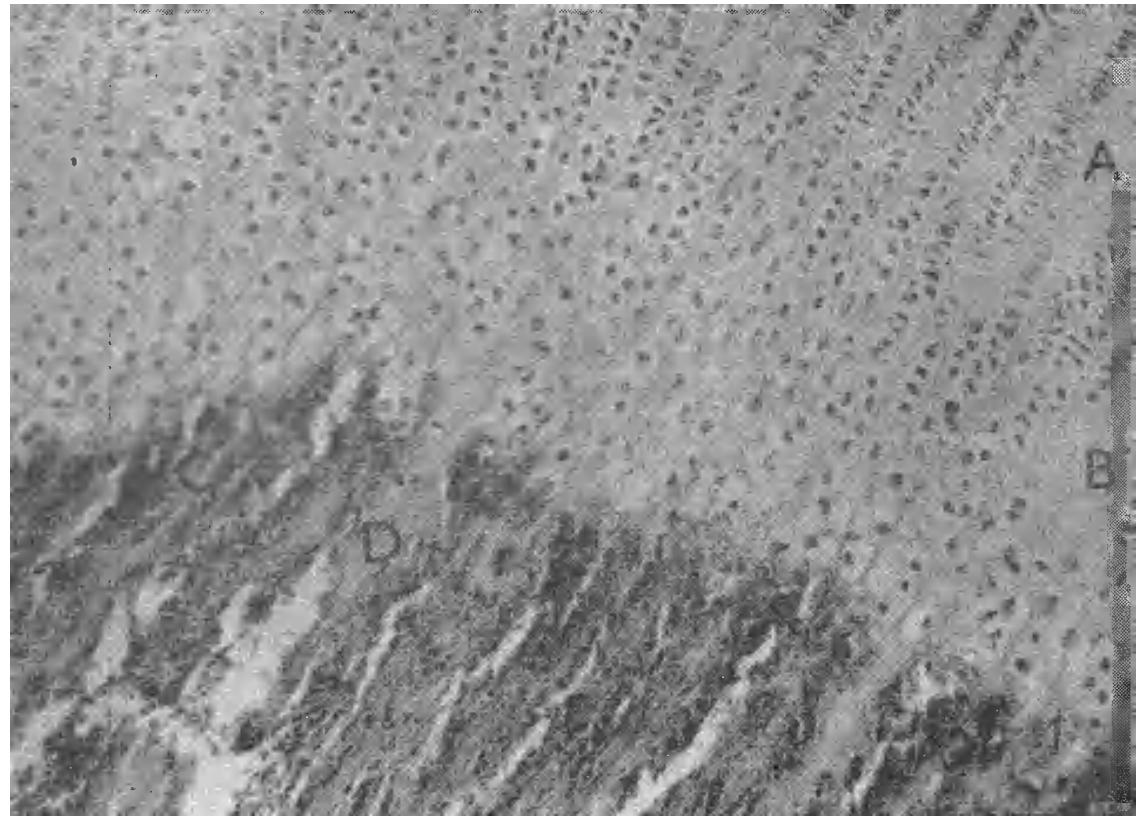

1 ॥

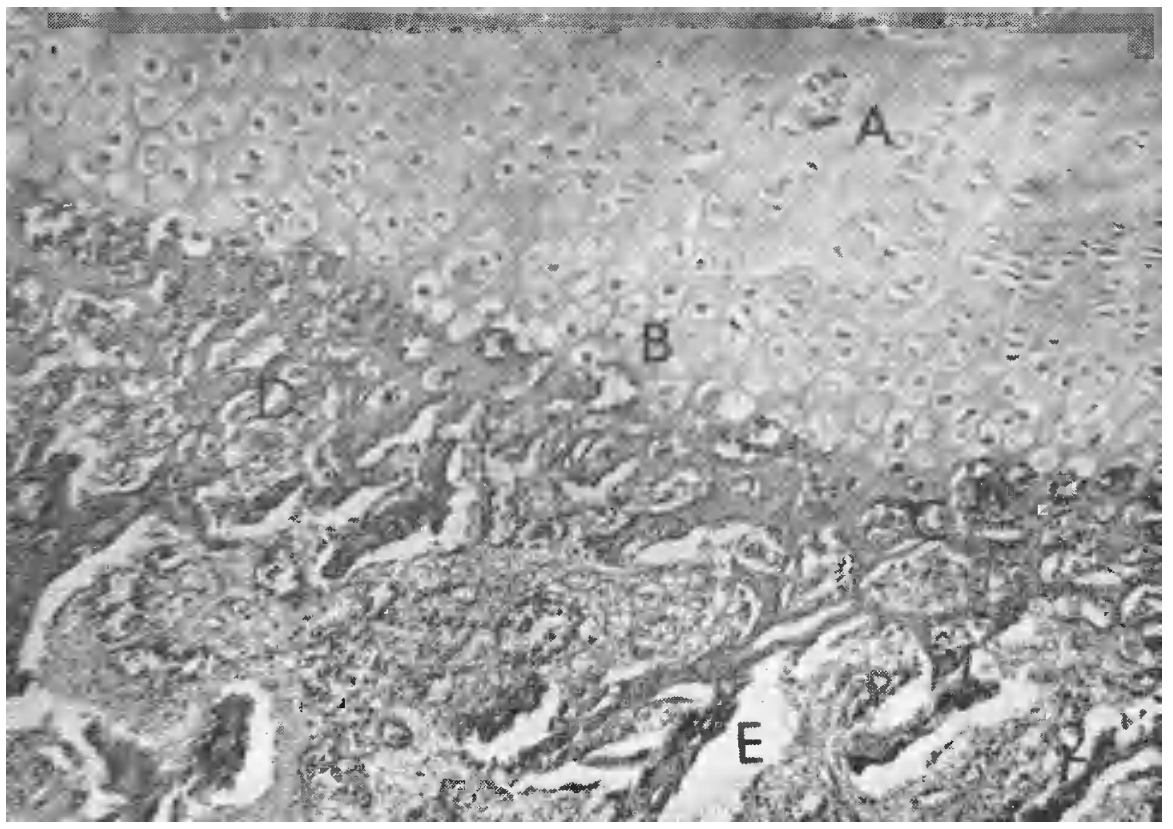


spongiosa of the tuber coxae originates, the primary trabeculae of the spongiosa of the pelvic bones originate from the distal ossification zone.

A calcified hypertrophic cartilage forms the distal end. Characteristic for this structure is hypertrophy of the chondrocytes and along with it a decrease of the ground cartilage substance. Another character of the ground substance of the calcified hypertrophic cartilage is its mineralization which causes the original basophilic cartilage to be eosin-staining. In the initial stage of total ossification of the growth cartilage eosinophilia is transferred also to the ground substance of the middle cartilage layer.

In their initial stage, the hypertrophic chondrocytes are grouped into isogenetic groups with increasing mineralization and decrease of the ground substance they are arranged into columns.

In the processes of the growth cartilage the ossification takes place in a similar way as in the transverse parts of the cartilage with the only difference in that the middle part of the processes is filled up with the growing cartilage and the peripheral parts are formed by a hypertrophic cartilage the ground substance of which is subject to gradual enchondral mineralization.

As stated above, the hypertrophic chondrocytes of the calcified cartilage at the distal end of the growth cartilage are arranged into columns. This palisade-like arrangement of chondrocytes conditions, at the same time, also changes in the ground substance of the cartilage. The ground substance marginating the initially isogenetic groups of chondrocytes of the normal cartilage changes its arrangement and is ranged into strips between the palisades of chondrocytes. Another change observed is the change in the uptake of the dye by the basic substance of the cartilage caused by its provisional mineralization. The individual columns are separated by clearly evident strips of the basic mineralized substance which, in the further process of mineralization, remain in their place and acquire the function of direction trabeculae.

Simultaneously with osteogenesis on the peripheral ends of the growth cartilage the activity can be observed of clastic elements associated with the destruction of the cartilage and with the formation of primary marrow cavities.

The destruction of cartilage and growing through of the blood vessels gradually enlargens the primary marrow cavities and on the peripheries of these cavities osteoid zones are formed due to the activity of osteoblasts.

The destruction of cartilage on the distal end takes place in the line of erosion where intensive destruction takes place of the hypertrophic chondrocytes and basic mineralized substance of the calcified hypertrophic cartilage down to the so called direction trabeculae.

On the surface of the direction trabeculae differentiation of osteoblasts can be

Fig. 1. Normal structure of the enchondral ossification of the apophyseal cartilage (HE, $\times 95$ ). A - hypertrophic cartilage, B - calcified hypertrophic cartilage with column-like arrangement of hypertrophic chondrocytes, C - erosion line, D - osteoid zone with marked and straight direction trabeculae.

Fig. 2. Changed structure of the enchondral ossification of apophyseal cartilage (HE, $\times 95$ ). A - hypertrophic cartilage, B - calcified hypertrophic cartilage with hyfertrophic chondrocytes forming cell clusters, $\mathrm{C}$ - erosion line, $\mathrm{D}$ - changed osteoid zone with deformed direction trabeculae, $\mathrm{E}$ - ossiform zone with enlarged intertrabecular spaces. 


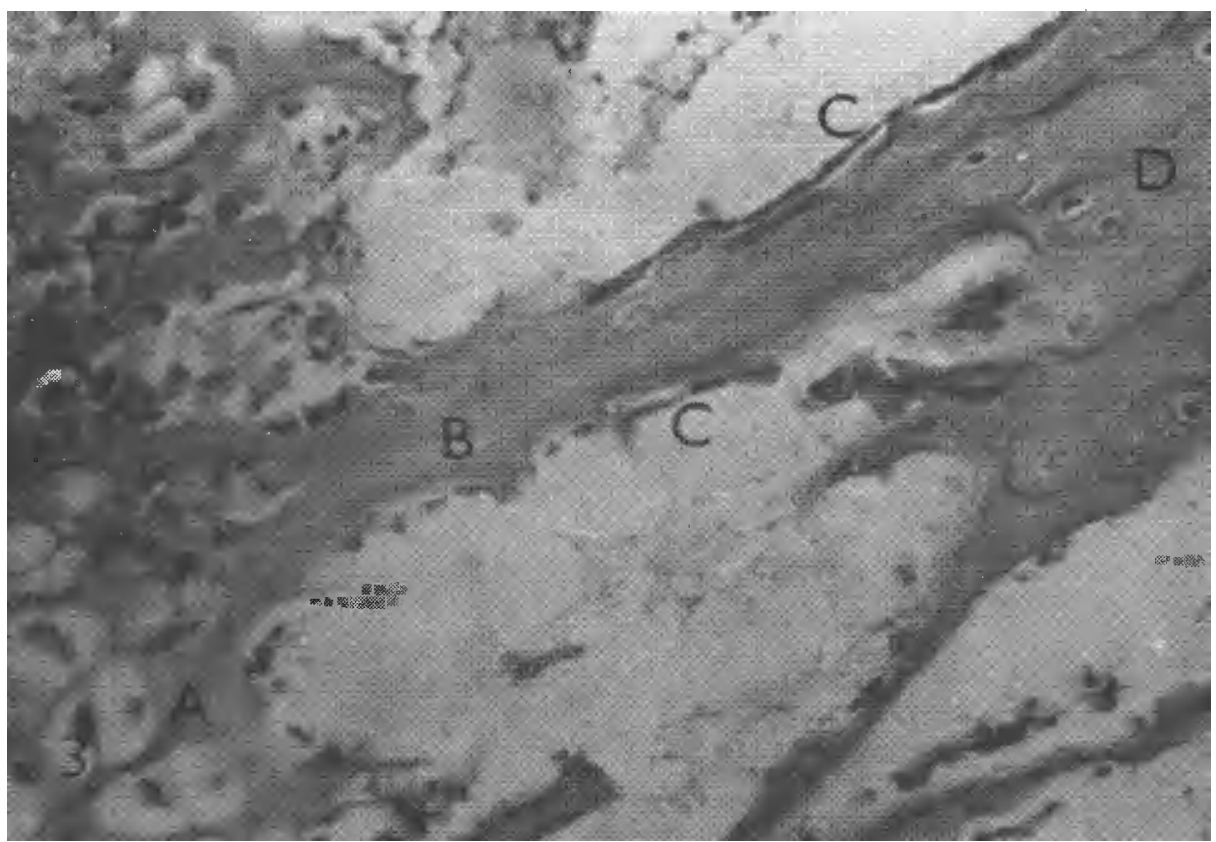

3 4

V 4

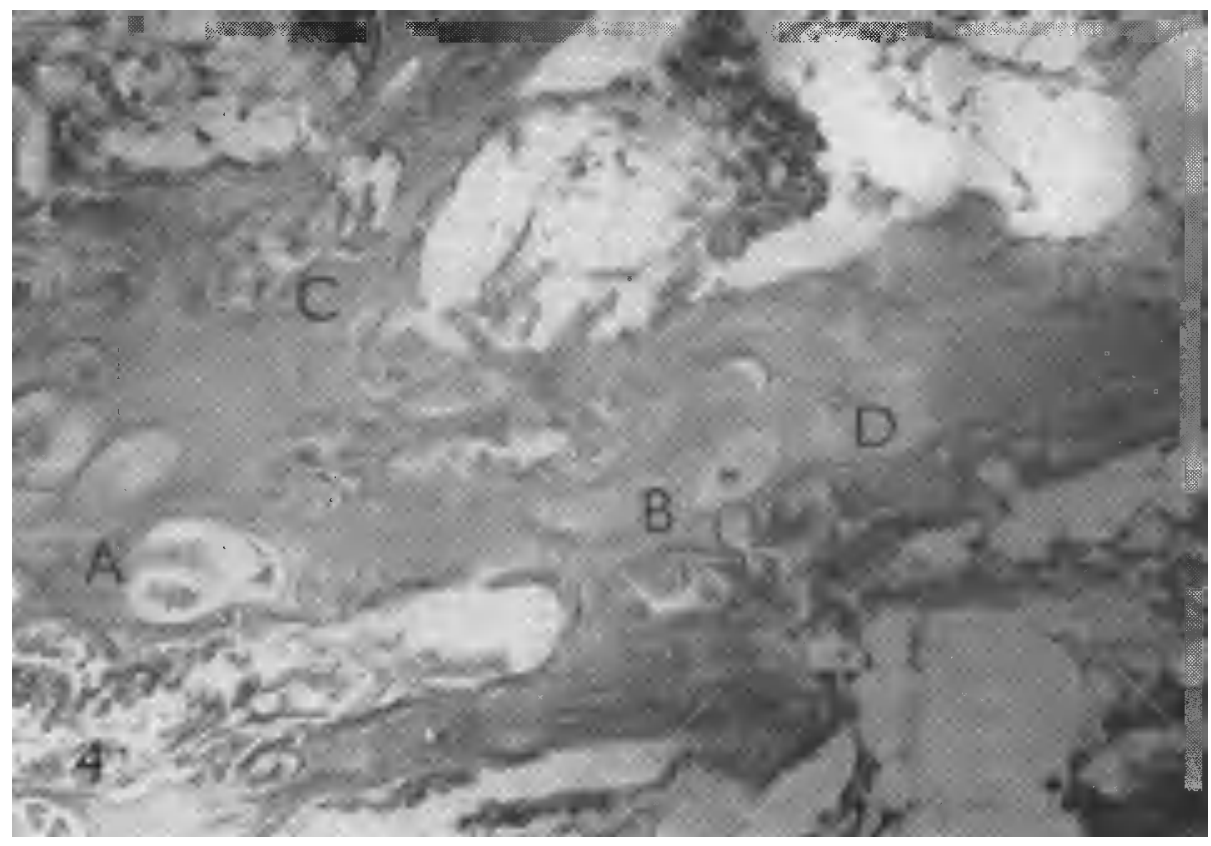


observed which secrete the non-mineralized ground bone substance indicated as osteoid. The osteoid tissue is very well differentiated in stain from the bone tissue. Along with the formation of the osteoid zone resorption can be observed of the direction trabeculae and deposition of bone mineral into the osteoid tissue.

\section{Spongious bone of the ala ossis ilium}

Resorption activity can be observed in primary spongiosa which causes an enlargement of the marrow cavities. The trabeculae of spongiosa separate and the intertrabecular spaces increase. In the marrow cavities the reticular connective tissue with cell elements of the bone marrow gradually differentiate. In the spongious layer remains of undestroyed tissues of direction trabeculae can often be observed in the central part of the trabeculae; they gradually disappear so that the trabeculae consist of individual lamellae, running parallel to the surface, and bone cells. The trabeculae of spongiosa of the pelvic bones are connected through intertrabecular anastomoses so that they form a spatial anastomosing network. The trabeculae of the normal, unchanged structure are stained evenly.

\section{Changes in the morphological structure}

The disorders of mineral metabolism caused by the lack of osteotrophic elements give rise to changes in the morphological structure of the cartilage and bone tissue. Generally, these changes can be characterized as an insufincient mineralization of the ground substance. The disorders in mineralization have to do both with the ground substance of the calcified hypertrophic cartilage and the ground substance of the bone tissue. The changes given provide a characteristic picture connected with the decrease of bone mineral mostly with no loss of the bone substance.

From this point of view it is possible to divide the pathological changes in the bone bioptic samples into changes dependent on the cartilage or the spongious structure of the bone tissue.

In the hypertrophic cartilage of young animals - feedlot bulls - insufficient provisory mineralization of the ground substance occurs, whereas in the trabeculae of the spongiosa demineralization of the already previously mineralized ground bone substance appears later.

For the qualitative evaluation of changes of the structure of bone bioptic samples very important is the evaluation of the following structures: apophyseal growth cartilage and the trabeculae of the spongiosa of pelvic bones.

Disorders of mineral metabolism of all degrees are manifested in the change of the growth cartilage structure which appear in the bone bioptic samples of the tuber coxae. Especially typical are changes at the distal end of the growth cartilage which affect the continuous enchondral ossification zone.

Fig. 3. Detail of the direction trabecula with normal structure $(\mathrm{HE}, \times 300)$.

A - hypertrophic chondrocytes, B - direction trabecula, C - osteogenic cellular elements on its surface, $\mathrm{D}$ - secreting osteoblasts lined by osteoid tissue.

Fig. 4. Osteoid zone of the enchondral ossification (HE, $\times 300)$.

A - hypertrophic chondrocyte, B - hypertrophic chondrocyte in the direction trabecula, C piercing capillary, D - ground cartilaginous substance. 


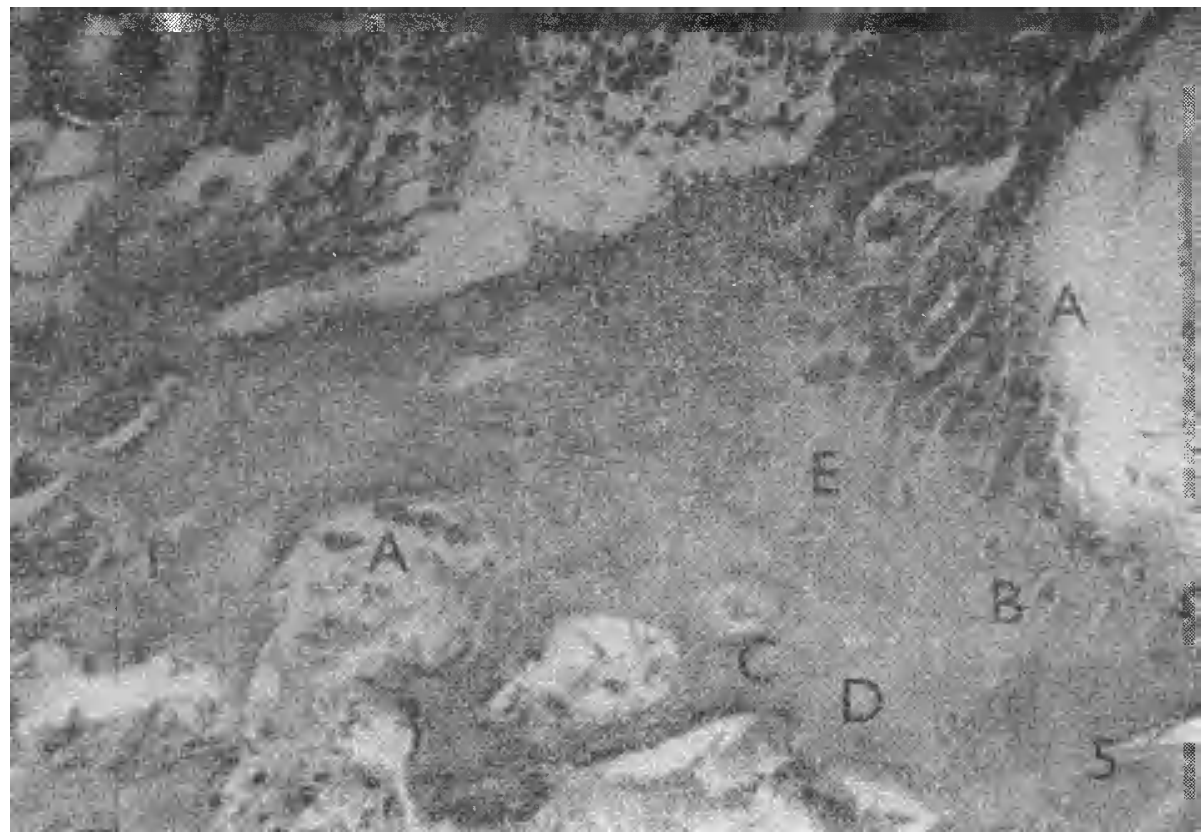

5 \

จ 6

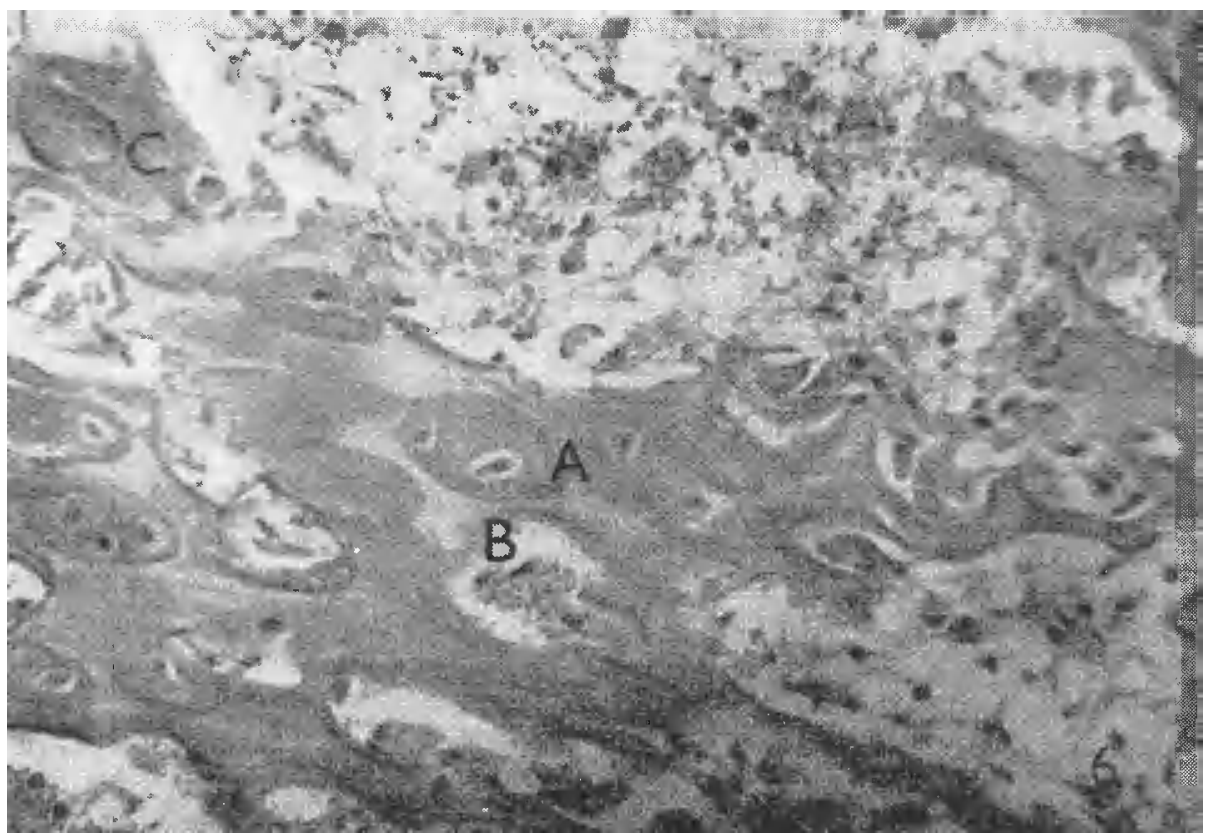


With a moderate form of metabolic disorders slight disorders in the mineralization of the ground substance in the zone of hypertrophic calcified cartilage appear. It is true that hypertrophic chondrocytes are arranged into columns but between the individual columns we can observe clusters of chaotically arranged cells which lost the typical image of a cell column. The insufficient mineralization of the ground substance of the cartilage between the columns of cells enables their different arrangement. At the same time we can observe a prevalence of cartilage resorption which is manifested in an increased formation of primary cavities. Destroyed are also insufficiently mineralized direction trabeculae and their fragments shift into the originated bone tissue of the spongious trabeculae.

In cases of more serious metabolic disorders also the structure of the growth cartilage undergoes more expressive changes. The destruction of the cartilage and primary spongiosa is so expressive that it completely prevails over chondrogenesis and osteogenesis.

On the distal end of the enchondral zone changes appear afflicting the cell elements and the ground substance of the cartilage. The cells are arranged into isogerietic groups and they form clusters of hypertrophic chondrocytes. The ground substance of the cartilage between the clusters of cells is not mineralized and therefore the cell elements lack the support of trabeculae for the formation of columns. Close to the margin of the ossification zone we can observe the destruction of the cartilage connected with the formation of primary cavities. The insufficiently mineralized ground substance with the cell elements remains unchanged; it is shifted into other zones which are formed in the process of ossification. These structures can then be found in the osteoid, ossiform zone, and also in the wide intertrabecular spaces between the reticular fibres of the bone marrow. The total histological picture shows that the normally originating cartilage is not substituted by bone tissue to a sufficient extent and in time. In the histological picture the predominance of resorptive activity over the building activity can be observed. In younger animals the reactions on growth cartilage described are especially expressive.

Together with changes in the structure of the distal end of the growth cartilage also changes in the other zones of ossification are seen. In these layers atypical structures are found. The cartilage shifts, together with fragments of the ground substance, into the osteoid and ossiform zone. It is very often found also in the centre of bone trabeculae. Primary spongiosa is to a larger extent resorbed and the intertrabecular spaces are considerably wide.

The changes are manifested by the formation of osteoid margins on the surface of the individual trabeculae which are well differentiated in colour. The osteoid margins, to a various extent cover the calcified surface of the trabeculae from the side of the marrow cavities. The thickness of the osteoid margins formed is not

Fig. 5. Differentiation of the osteogenic cells (HE, $\times 300$ ).

A - osteogenic cell elements, B - secreting osteoblasts, C - hypertrophic chondrocyte, D ground cartilaginous substance, $\mathrm{E}$ - osteoid tissue, F - piercing capillary in the erosion line.

Fig. 6. Osteoid zone of the enchondral ossification (HE, $\times 300$ ).

A - secreting osteoblasts with the osteoid formed, B - ground cartilaginous substance, C - polynuclear clastic element. 


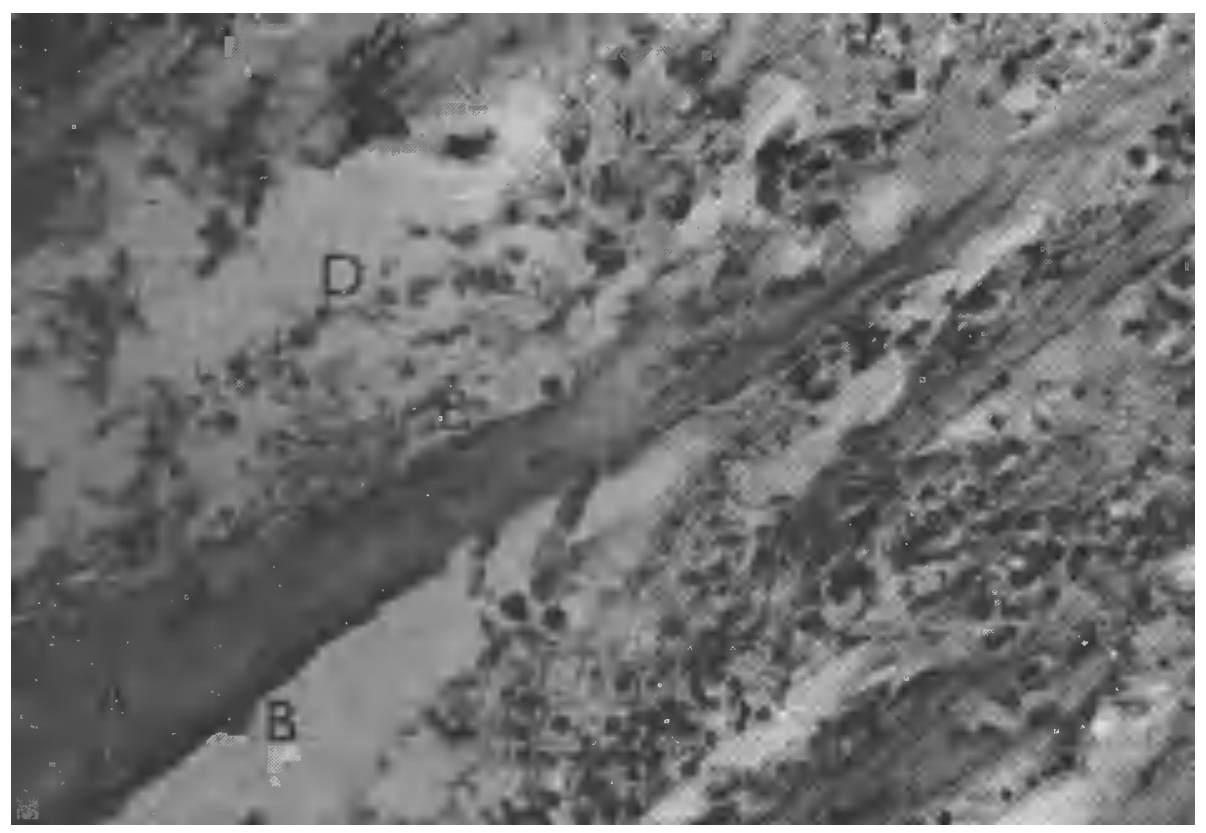

7 A
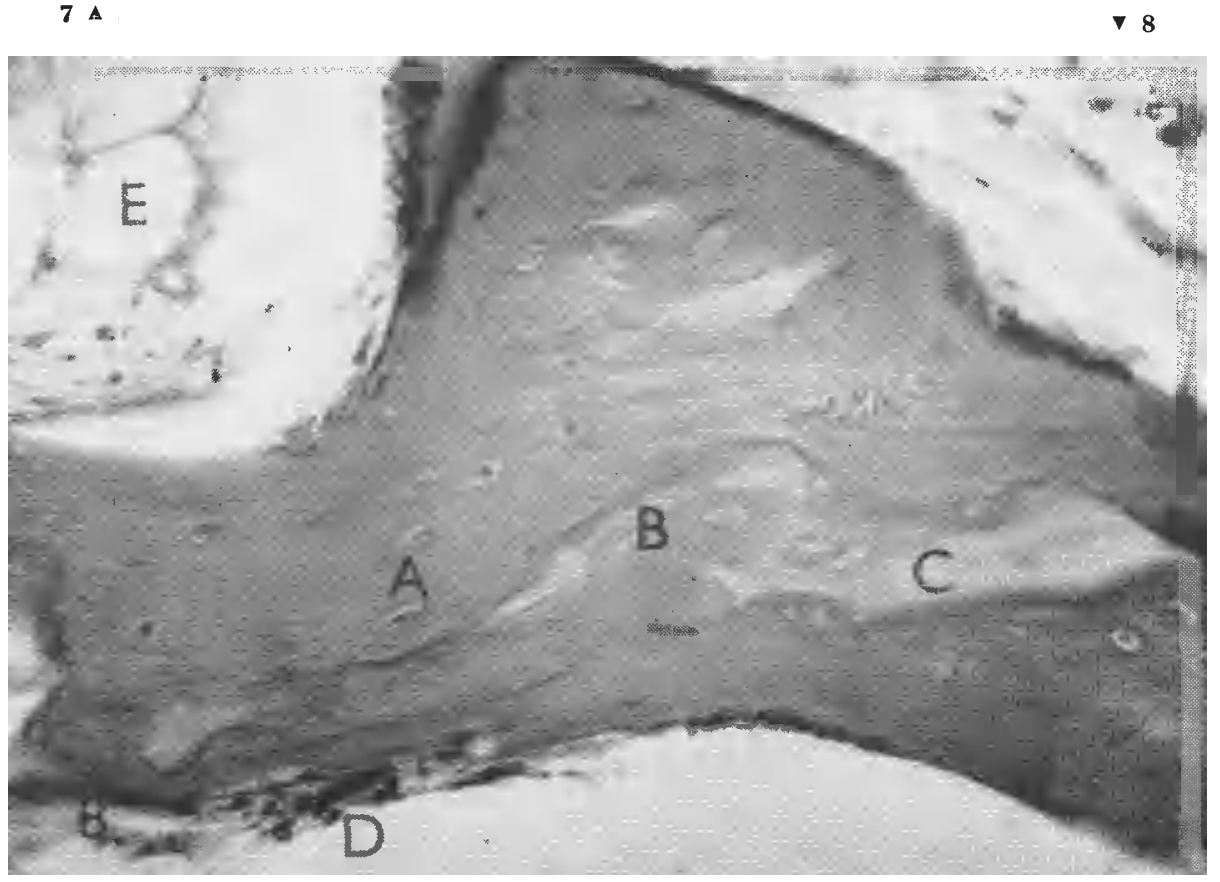
the same and in some cases they join the trabeculae running alongside with osteoid anastomosis.

Only sporadically was the occurrence observed of osteoid tissue around the lacunae in the form of perilacunary margins and around the bone channels. The author cannot confirm the increase in the amount of clastic elements in the bone tissue.

\section{Discussion}

Histological findings of intravitally sampled bone tissue considerably improve the diagnosiiz system of generalized osteopathies occurring in cattle in connection with disorders of mineral metabolism.

The author is of the same opinion as J a g oš et al. (1975) that the hitherto diagnostics of subclinical disorders of mineral metabolism performed on the basis of mere biochemical examinations of blood and urine are insufficient. Compensatory systems of the organism are so effective that for a long time they maintain the stability of internal body compartments and prevent fluctuations in the concentration of calcium and inorganic phosphorus. This compensatory mechanism acts to a certain extent also in such cases when the organism uptakes or utilizes these elements to an insufficient degree.

From the above mentioned in follows that demineralization of the ground bone substance occurs much sooner than the decrease of plasmatic calcium and inorganic phosphorus appears. Changes in the level of these elements are not found until the clinical manifestation of the disorder appears (Priboth et al. 1968, Jagoš et al. 1975).

In a normal structure of the bone ground substance there is a regular exchange of bone mineral which takes place on several levels. In the first stage only the mineral availability, the so called mineral pool, changes, representing the readily metabolizable proportion of calcium absorbed in cases when the organism needs it and the release of calcium ions is very prompt.

The surface of the crystallites represents highly hydrated systems and calcium bound in this way becomes a mobile calcium fraction from which it can be readily released if its consumption is increased.

Finally, also the organic matrix of the ground bone substance connected with its destruction can be exchanged.

According to his own findings the author can prove that demineralization in the course of the subclinical form is realized mainly in the loss of minerals from the ground substance of the bone tissue without its increased degradation, i.e. without the destruction of the organic bone matrix.

The demineralization process begins after the exhaustion of the mineral pool and exchange of crystallites. The crystallites are bound to the collagen fibrils of

Fig. 7. Detail of the direction trabecula $(\mathrm{HE} \times 300)$

A - ground cartilaginous substance, B - osteogenic cells arranged on the surface of trabecula, $\mathrm{C}$ - secreting osteoblasts, D - osteogenic bone marrow with blastic elements and erythrocytes.

Fig. 8. Trabecula of the newly-formed spongious bone $(\mathrm{HE}, \times 300)$

A - osteocytes, B - secreting osteoblasts, C - intact ground cartilaginous substance, D osteogenic cell elements, $\mathrm{E}$ - bon.e marrow. 


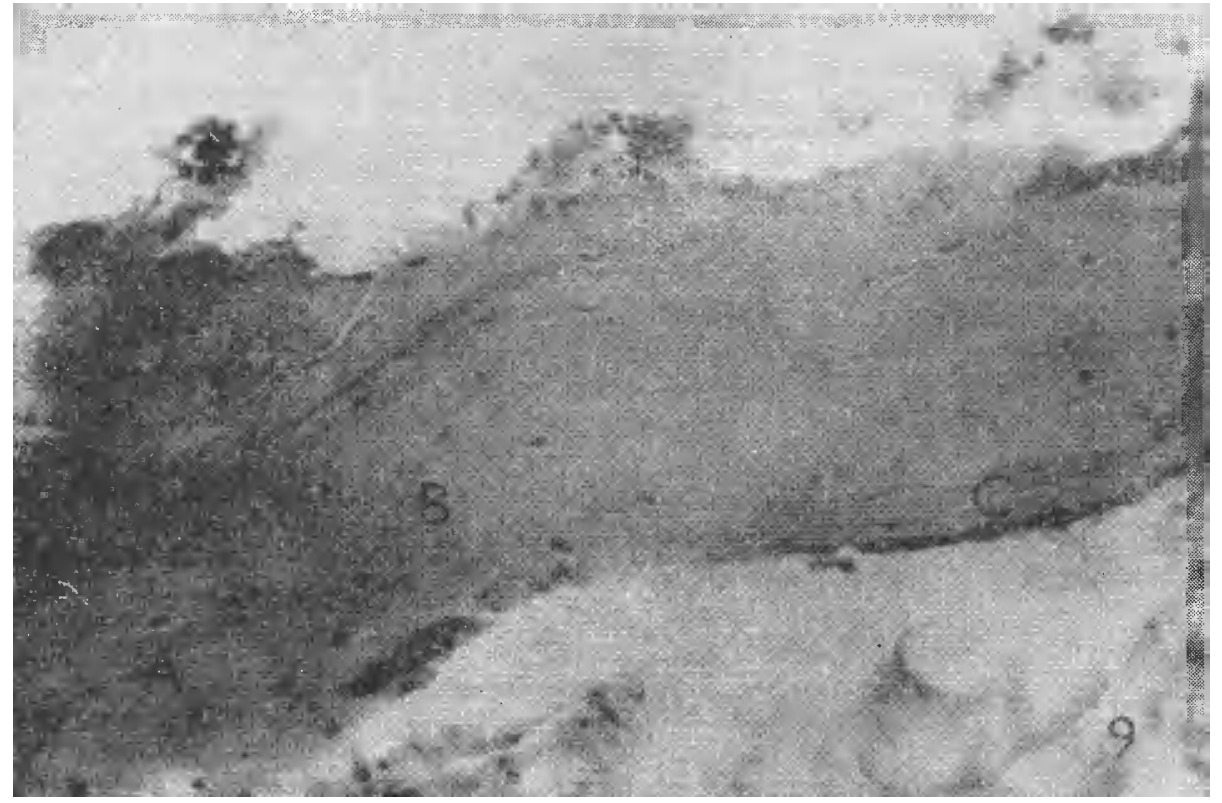

9 \

$$
\text { จ } 10
$$




the ground substance and after their consumption the ,uncoverings of these collagen fibrils occurs which are differentiated in colour as osteoid tissue. Under normal conditions the formation and degradation of bone tissue is balanced. If the exchange of calcium and phosphorus is impaired the degradation of the ground bone substance predominates and on the surface of the trabeculae of the opongy bone osteoid margins are formed. In the superficial lamellae of the trabeculae calcium is degradated and these layers are demineralized by halisteresis.

Accord ing to the author's opinion the process originating on the surface of the trabeculae is a combined one. The osteoid margins are formed not only by halisteresis but also the new non-mineralized osteoid tissue participates in this formation, originating through the secretion activity of blastic elements and is deposited by apposition in endostal ossification. The osteoid margins, along with the changes on the growth cartilage, are the most pronounced morphological changes occurring with disorders of mineral metabolism.

The author cannot agree with some data quoted by Priboth, Sefner, Wujanz (1968). According to these authors gradual destruction of the bone on the surface of the trabeculae does not occur, but demineralization begins within the trabeculae in the surroundings of bone lacunae and channels. On these formations the destruction of calcium occurs with a change of the organic matrix of the ground substance with a formation of perilacunary areas.

Rowland (1966) in his autoradiographic study using ${ }^{45} \mathrm{Ca}$ proved that within a very short period the exchange of calcium ions on all surfaces of the bone occurs: on the endostal, periostal, haversian systems, Volkmann's channels, surface of the cortical bone and on the surface and channels of spongiosa trabeculae. Also Groer and Marshall (1973) confirm these findings. Using ${ }^{45} \mathrm{Ca}$ the authors proved that the exchange of calcium occurs on all bone surfaces. This exchange takes place in the peripheral zone which is $1-4 \mu \mathrm{m}$ wide.

On the basis of these studies the surface is not only the area on the trabecular surface but the bone surface is also that part which marginates the lacunae or bone channels. Therefore, demineralization occurs on all surfaces, just the same as the exchange of calcium under physiological conditions.

According to the author's observations the superficial margins are more distinct which is evidently due to their increase by the new osteoid tissue originated through apposition with endostal ossification on the trabecular surface. In the author's opinion the assertion that demineralization begins within the trabecula substance cannot be univocally accepted.

The author can confront his own findings only with the studies of Priboth, Sefner, Wujanz (1978). Studies of these authors deal with the chemical analysis and morphological examination of bioptic samples of the bone tissue of cattle

Fig. 9. Trabecula of the definitive bone (HE, $\times 300)$.

A - osteocytes, B - ground mineralized bone tissue substance, $\mathrm{C}$ - endostal ossification on the trabecular surface.

Fig. 10. Trabecula of the spongious bone with enlargened lacunae in incipient remodelling (HE, $\times 300$ ).

A - lacunes with remnants of the chromatin nucleus substance of osteocytes. B - osteocyte, C - differentiating osteogenic cell elements. 

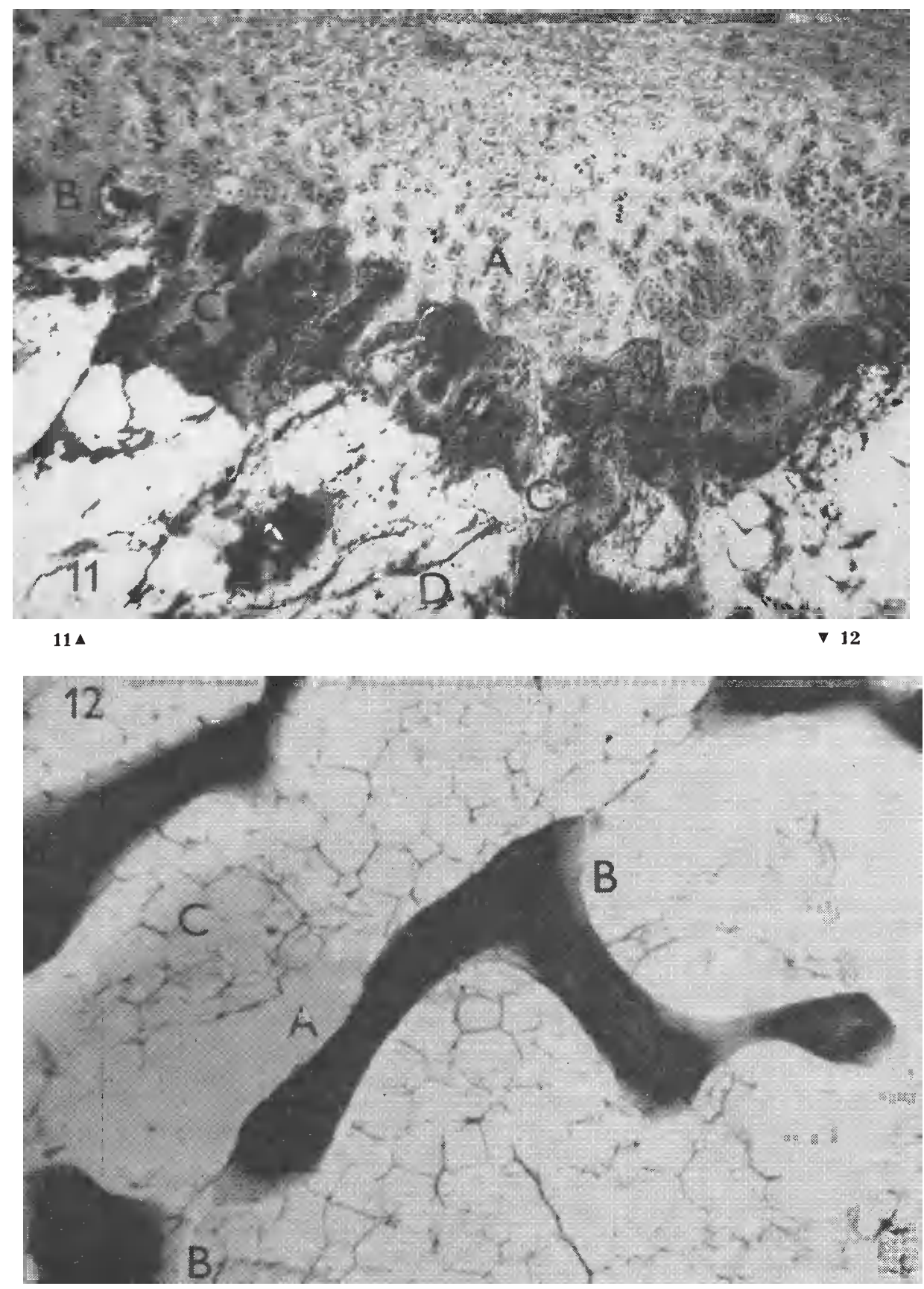
with disorders of mineral metabolism and at the present time they are only the ones of the kind.

When evaluating changes of the morphological structure the authors divide the changes found into two groups according to the age of the animal; changes manifested on the cartilage and changes on the bone tissue. In young animals the cartilage responds more, in older animals changes on the bone tissue occur and no structural changes are observed on the cartilage. The author can confirm the findings of Priboth et al. (1968).

Further examination, i.e. chemical analysis of the spongious structure, no doubt contributes to an objective evaluation of morphological changes in bioptic samples of the bone tissue.

Morphological examination of all the structures of bioptic samples with regard to the quantitative value of the inorganic substance of the bone tissue can thoroughly and objectively evaluate both data and find a common result.

\section{Strukturální hodnocení chrupavky a kostní tkáně skotu z funkčně morfologického hlediska}

V 82 cylindrech kostní tkáně získaných osteobiopsií tuber coxae modifikovanou metodou podle Bartelheimera bylo provedeno hodnocení morfologických struktur $\mathrm{s}$ ohledem na změny vyvolávané poruchami minerální látkové výměny u býků ve věku $8-12$ měsíců.

Kostní cylindry byly bezprostředně po provedeném odběru fixovány. Tkáňové řezy byly barveny hematoxylin-eosinem, Azanem a podle Goldnera. Za použití různých barvicích metod byla získána řada korelátů, jejichž zhodnocení poskytuje větší objektivnost nálezů a opravňuje $k$ vyjádření obecných závěrů.

Morfologické vyšetření struktur kostních bioptátů ukazuje, že poruchy v minerální látkové výměně vyvolávají změny morfologické struktury, které se u mladých jedincủ manifestují především na apofysární růstové chrupavce a $\mathrm{v}$ některých prípadech na trámcích spongiosní kosti.

Změny na chrupavce postihují především její distální okraj se souvislou enchondrální osifikační zónou. Zóna hypertrofické chrupavky zvápenatělé se prodlužuje a jednotlivé hypertrofické chondrocyty se neřadí do sloupců, nýbrž vytvárejeji neuspořádané skupiny buněk. Základní hmota chrupavky je nedostatečně mineralizována, odlučuje se ve fragmentech, které se posouvají do dalších osifikačních zón. Zde je prokazujeme jako atypické struktury.

Demineralizace postihuje také trámce spongiosní kosti, na jejichž povrchových, endostálních plochách, méně kolem lakun a kostních kanálkủ, zachycujeme vytvoření osteoidní tkáně. Osteoidní tkáň se velmi dobře barevně v histologických preparátech diferencuje.

Fig. 11. Markedly changed structure of the apophyseal cartilage and osteoid zone $(\mathrm{HE}, \times 95)$. A - groups of hypertrophic chondrocytes, B - erosion line, C - direction trabeculae deformed in consequence of defficient mineralization of the ground cartilaginous substance, $D-$ wide intertrabecular spaces.

Fig. 12. Demineralization of trabeculae of the definitive spongious bone (Goldner, $\times 95$ ). A - trabecula, B - osteoid lining on the trabecular surface caused by demineralization of the ground bone tissue, $\mathrm{C}-$ intertrabecular space. 
Použité metodiky zpracování, jak ukazují vlastní nálezy, dovolují z obecného hlediska poukázat na možnost intravitální diagnostiky strukturálních změn, ke kterým dochází při poruchách minerální látkové výměny.

\section{Структуральная оценка хряща и костной ткани крупного рогатого скота с функционально-морфологической точки зрения}

В 82 цилиндрах костной ткани, полученных остеобиопсией из tuber coхае модифицированным методом по Бартельгеймеру, проводилась оценка морфологических структур с учетом изменений, вызванных нарушениями минерального обмена вещества у быков в возрасте 8-12 месяцев.

Костны цилиндры после проведенного взятия пробы непосредственно фикскровались. Пласты ткани были окрагцены гематоксилин-зозином, Азаном и по Гольднеру. С помощью различных методов окращивания был получен ряд коррелятов, оценка которых придает большую объективность анализам и способствует формулировке общих выводов.

Морфологическое исследование структур костной ткани показывает, что нарушения минерального обмена веществ вызывают изменения морфологимеской структуры, которые у молодых животных проявляются прежде всего - области апофизарного ростового хряща и в некоторых случаях в спонгиозной кости.

Изменения хряща касаются прежде всего его дистального края с непрерывпой энхондральной зоной оссификации. Зона гипертрофического хряща кальқифицированного удлиняется и отдельные гипертрофические хондроциты не входят в колонки, а образуют беспорядочные группы клеток. Основная масса хряща недостаточно минерализована, отделяется фрагментами, которые перемещаются в следующие зоны оссификацик. Здесь их можно наблюдать в качестве атипических структур.

Деминерализация касается также основы спонгиозной кости, на поверхмости әндостальной плоскости которых - в меньшей степени около просветов и костных канальцев - наблъдается образование остеоидной ткани. Посхеднюю можно в гистологических препаратах очень хорошо отличить по мвету.

Используемая методика обработки - соответственно собственным результатам - позволяет в общих масштабах обратить внимание на возможность внтриклеточного диагноза структуральных изменений, имеющих место в результате нарушения минерального обмена вещест.

\section{References}

ALCOCK, N. W.: Calcification of cartilage. Clin. Orthop., 86, 1972: 287-311.

ARNOLD, J. S. - FROST, H. M. - BUSS, R. O.: The osteocyte as a bone pump., Clin Orthop., 78, 1971: $47-55$.

ASCENZI, A.: The relationship between mineralization and bone matrix. In: Bone and Tooth (H. J. Blackwood, ed.), New York: The Macmillan, Co., 1964.

BARTELHEIMER, H.: Die klinische Bedeutung der Knochenbiopsie. Verh. Dtsch. Ges Path., 47, 1963: 129 .

BARTELHEIMER, H. - PAHLKE, G. - SCHMITT-ROHDE, J. M.: Die Knochenbiopsie in der Diagnostik von generalisierten Osteopathien und Knochenmarksveränderungen. Med. Bild, 2, 1959: 48. 
BIGGAR, G.: Experimental studies of apatite crystallization in parts of the system. $\mathrm{CaO}$ $-\mathrm{P}_{2} \mathrm{O}_{5}-\mathrm{H}_{2} \mathrm{O}$ at 1000 bars., Min. Masg., 35, 1966: 1110-1122.

BLOOM, W. - BLOOM, M. A.: Calcification of developing bones in embryonic and newborn rats. Anat. Rec., 78, 1940: 497-514.

BONUCCI, R.: The locus of initial calcification in cartilage and bone. Clin. Orthop., 78, 1971: $108-139$.

BURKHARDT, R.: Knochenbiopsie. Internist, 11, 1970(a): 351.

CAMERON, D. A.: The fine structure of bone and calcified cartilage. Clin. Orthop., 26, 1963: 199-228.

CAMPO, R. D.: Protein-polysaccharides of cartilage and bone in health and disease. Clin. Orthop., 68, 1970: $182-209$.

CAMPO, R. D. - TOURTELLOTTE, C. D.: The composition of bovine cartilage and bone. Biochim. biophys. Acta, 141, 1967: 614-624.

ČERYÝ, H.: Hodnocení morfologické struktury $\mathrm{v}$ kostních bioptátech skotu vzhledem $\mathrm{k}$ poruchám minerálního metabolismu. Thesis, Brno, 1977.

ČERNÝ, H.: Klasifikace kostních bioptátů $\mathrm{z}$ tuber coxae $\mathrm{s}$ možností určení skeletového věku skotu (v tisku).

DEQUEKER, J. - REMANS, J. - FRANSSEN, R. - WAES, J.: Ageing patterns of trabecular and cortical bone and their relationship. Calc. Tiss. Res., 7, 1971: 23.

DIXON, B.: Regional variation in the cycle time of cells in epiphyseal cartilage. Europ. J. clin. Biol. Rec., 15, 1970: 875-878.

FIELD, R. A. a kol.: Bone composition in cattle, pigs, sheep and poultry. J. Anim. Sci., 39, (3), 1974: 493-499.

GALANTE, J., ROSTOKER, W., RAY, R. D.: Physical Properties of Trabecular Bone. Calc. Tiss. Res., 5, 1970: 236-246.

GRAEBNER, R : Die Knochenpunktion beim Rind. Technik und Instrumentarium, Berlin. u. Münch. tierärztl. Wschr., 74, 1961: 253.

GROER, P. G., MARSHALL, J. H.: Mechanism of Calcium Exchange at Bone Surfaces. Calc. Tiss. Res., 12, 1973: 175-192.

HOLTROP, M. E.: The hypertrophic chondrocyte. Calcif. Tiss. Res., 9, 1972(b): 140-151.

HOLTROP, M. E.: The ultrastructure of the epiphyseal plate. 1. The flattened chondrocyte. Calcif. Tiss. Res., 9, 1972(a): 131-139.

IRVING, J. T. - WUTHIER, R. E.: Histochemistry and biochemistry of calcification with special references to the role of lipids. Clin. Orthop., 56, 1968: 237-260.

JAGOS et al.: Výzkum karencí minerálních látek při metabolických poruchách. Project report, VÚVL II-4/5, Brno, 1975.

KEMBER, N. F.: Comparative patterns of cell division in epiphyseal cartilage plates in the rat. J. Anat. Lond., 111, 1972: 137-142.

KNESE, K. H.: Zell- und Faserstruktur des Knochengewebes. Acta anat., 53, 1963(b): 369-394, Basel.

KNESE, K. H.: Osteoklasten, Chondroklasten, Mineraloklasten, Kollagenoklasten. Acta anat., 83, 1972: $275-288$.

KNESE, K. H. - KNOOP, A. M.: Chondrogenese und Osteogenese elektronenmikroskopische und lichtmikroskopische Untersuchungen. Z. Zellforsch., 55, 1961(b): 413-468.

KOLDA, J.: Srovnávací anatomie zviřat domácích se zřetelem $\mathrm{k}$ anatomii člověka, II. Nauk o kostech a chrupavkách, Novina, Brno, 1936.

MAZHUGA, P. M. - ZHITNIKOV, A. Y. - KHARCHUK, L. N.: Differentiation and reproduction of cells in chondrogenesis. Anat. Anz., 126, 1970: 172-181.

McLEAN, F. C. - BLOOM, W.: Calcification in normal growing bone. Anat. Rec., 78, 1940: $333-352$.

Nomina anatomica Veterinaria, Holzhausen, Vienna, 1968.

PRIBOTH, W.: Zum Problem der Fütterungsbedingten Skeletsystemerkrankungen bei Jungrindern. Mh. Vet. Med., 19, 1964: 45.

PRIBOTH, SEFNER, WUJANZ: Die Knochenbiopsie beim Rind-Möglichkeiten der chemischen und histologischen Untersuchung zur Diagnose mineralstoffmangelbedingter Osteopathien. Monatsh. Vet. Med., 23, 22, 1968: 868-871.

SKINNER, H. C. W.: Studies in the Basic Mineralizing System, $\mathrm{CaO}-\mathrm{P}_{2} \mathrm{H}_{5}-\mathrm{H}_{2} \mathrm{O}$. Calc. Tiss. Res., 14, 1974: 3-14.

SCHENK, R. K.: Zur histologischen Verarbeitung von unentkalkten Knochen. Acta anat., 60, 1965: 3-19.

SCHENK, R. K. - SPIRO, D. - WIENER, J.: Cartilage resorption in the tibial epiphyseal plate of growing rats. J. Cell. Biol., 34, 1967: 275-291. 
THEILER, A.: Untersuchungen über den Bau normaler und durch kalzium- und phosphorarme Nahrung veränderte Rinderknochen. Denkschr. Schweiz. Naturforsch. Ges., 68, 1932: 1.

VOKROUHLICKÁ, O. - HORN, V. - ERBEN, J.: Význam kostní biopsie v klasifikaci osteopatií chronicky hemodialysovaných nemocných. Cas. lék. čes., 114, 1975: 31-32; 975.

WUTHIER, R. E.: A zonal analysis of inorganic and organic constituents of the epiphysis during endochondral calcification. Calc. Tiss. Res., 4, 1969: 20-38.

WUTHIER, R. E.: Lipids of mineralizing epiphyseal tissues in the bovine fetus. J. Lipid Res., 9, 1968: $68-78$. 